\title{
CONSIDERING GENDER POWER DYNAMICS FOR SUPPORTING WORKFORCE NUTRITION
}

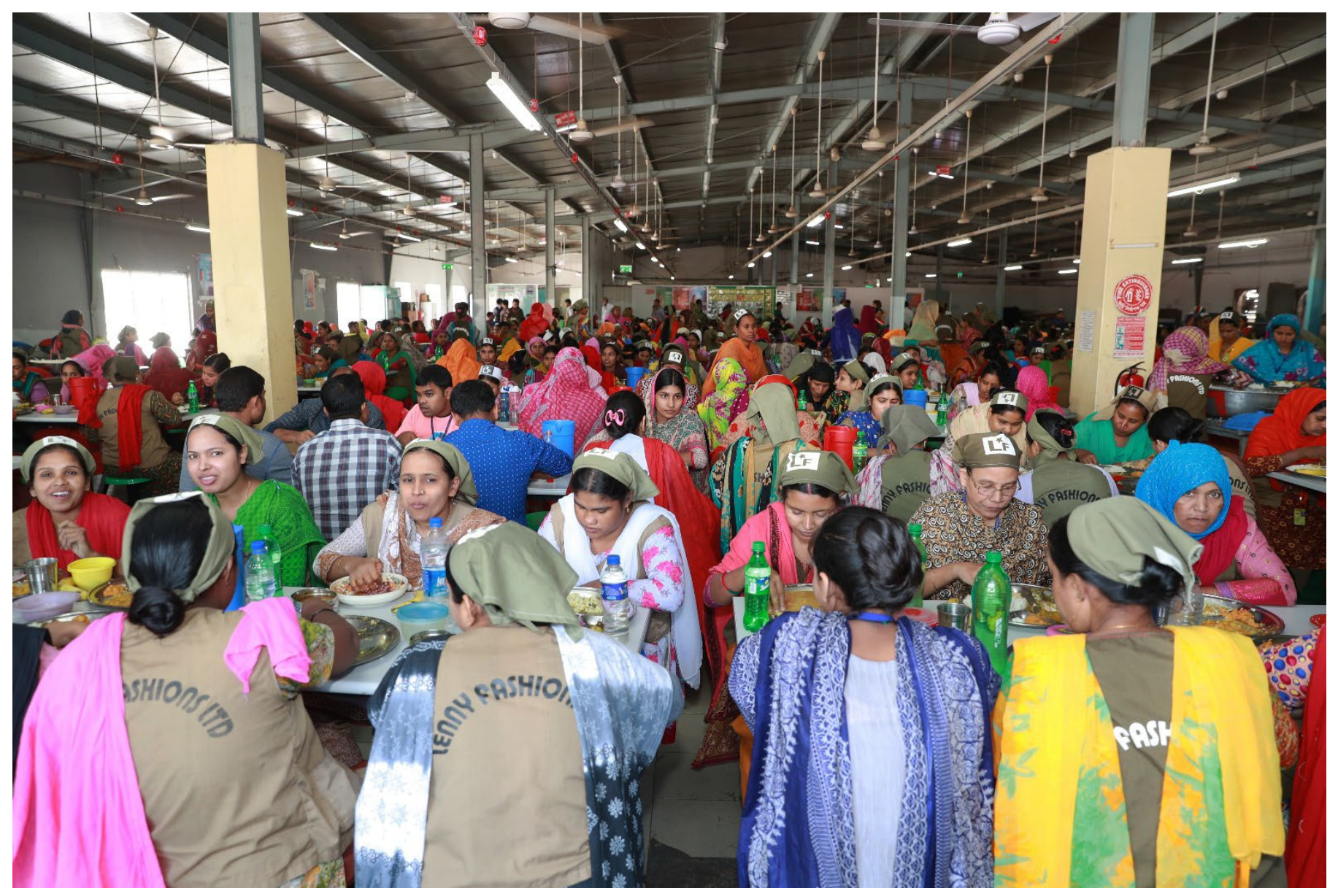

GAIN Working Paper n²6

March, 2022

Noora-Lisa Aberman, Amy van der Kaaij, and Janice Meerman

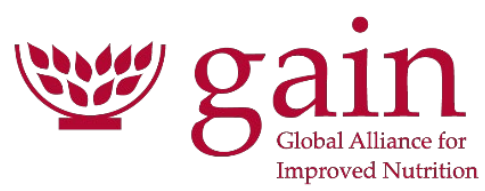




\section{ABOUT GAIN}

The Global Alliance for Improved Nutrition (GAIN) is a Swiss-based foundation launched at the UN in 2002 to tackle the human suffering caused by malnutrition. Working with governments, businesses and civil society, we aim to transform food systems so that they deliver more nutritious food for all people, especially the most vulnerable.

\section{Recommended citation}

Aberman N, van der Kaaije A. and Meerman J. Considering Gender Power Dynamics for Supporting Workforce Nutrition. Global Alliance for Improved Nutrition (GAIN). Working Paper \#26. Geneva, Switzerland, 2022. DOI: https://doi.org/10.36072/wp.26

\section{(c) The Global Alliance for Improved Nutrition (GAIN)}

This work is available under the Creative Commons Attribution-Non-Commercial-Share Alike 4.0 IGO licence (CC BY-NC-SA 4.0 IGO; https://creativecommons.org/licenses/by-nc-sa/4.0/). Under the terms of this licence, you may copy, redistribute, and adapt the work for non-commercial purposes, provided the work is appropriately cited, as indicated below. In any use of this work, there should be no suggestion that GAIN endorses any specific organisation, products or services. The use of the GAIN logo is not permitted. If you adapt the work, then you must license your work under the same or equivalent Creative Commons license. The contributions of third parties do not necessarily represent the view or opinion of GAIN.

\section{Acknowledgements}

Thanks to Genevieve Stone, Christina Nyhus Dhillon, Bärbel Weiligmann, Mirjam Kneepkens, and Saul Morris for their helpful comments, and to Stella Nordhagen for her valuable review. All photographs included in this document have been taken with consent for use in publications.

\section{GAIN WORKING PAPER SERIES}

The GAIN Working Paper Series provides informative updates on programme approaches and evaluations, research, and other topics relevant to helping reshape the food system to improve the consumption of nutritious, safe food for all people, especially the most vulnerable.

The Global Alliance for Improved Nutrition (GAIN)

Rue de Varembé 7

1202 Geneva

Switzerland

T: +41227491850

E: info@gainhealth.org

www.gainhealth.org 


\section{SUMMARY}

Promotion of nutrition in the workplace is a high-potential intervention for multiple reasons. Over half the global population spends one third of their adult life at work, and a third of the global population also suffers from some form of malnutrition. Additionally, workplaces are conducive to nutrition interventions as they provide a controlled, modifiable environment that facilitates sustained interaction with a 'captive audience'. However, as with all health-oriented interventions, successful promotion of nutrition in the workplace depends on identifying and addressing multiple sociocultural considerations. One of the most important of these is gender, which affects what, how, where, and if a person eats as well as other nutrition-related behaviours, such as breastfeeding, and an individual's attitude towards health more generally. This paper thus reviews prior research on gender issues in the workplace, with the objective of clarifying the implications of these norms for workplace nutrition programming in low- and middle-income countries. Findings indicate that discriminatory gender norms: 1) may limit women more than men in terms of their capacity to access healthy food at work and 2) may reduce the efficacy of workplace nutrition programmes, such as nutrition-focused health checks and breastfeeding support. From a programme perspective, these findings underscore the need to tailor workplace nutrition initiatives based on factors such as the male-to-female ratio of a given workplace's management structure, history regarding the treatment of female employees, and the presence of workforce welfare committees (or lack thereof).

\section{KEY MESSAGES}

- The health costs of unhealthy workplace food environments may be particularly high for women due to discriminatory gender norms that limit women's agency and purchasing power and may force them to seek employment in exploitative 'feminised' sectors, which do little to safeguard employee health and welfare.

- Workplace nutrition programmes have the potential to improve nutrition, but gender norms may reduce their impact. For example, men may be reluctant to participate due to norms of masculinity that discourage health-seeking behaviours, and women may struggle to act on messaging due to constraints on time and agency.

- Breastfeeding support is a critical subset of workplace nutrition initiatives. However even when supportive policies are in place, workplace breastfeeding facilities may not be used due to social and structural constraints.

- It is important to consider the capacity of a specific population of workers to take advantage of workplace-based nutrition programmes, as these may interact with gendered norms and agency with implications for women's and men's ability and willingness to utilise their services. 


\section{BACKGROUND AND OBJECTIVE}

Promotion of nutrition in the workplace is a high-potential intervention category for multiple reasons. First and foremost, much the global population spends a large share of their adult life at work, and a third of the global population suffers from some form of malnutrition (1). Additionally, workplaces are conducive to nutrition interventions as they provide a controlled, modifiable environment that facilitates sustained interaction with a "captive audience". From a private sector perspective, workplace nutrition initiatives demonstrate corporate responsibility and may also contribute directly to employee productivity. As such, employment-based nutrition actions provide excellent opportunities for public-private partnerships.

GAIN's Workforce Nutrition programme aims to leverage this potential to improve nutrition outcomes among workers in low- and middle-income countries (LMICs). The programme focuses on improving access to and demand for healthier diets using existing business structures as entry points. Currently, the programme works with partners in the tea sector (India and Kenya), cocoa sector (Ghana), and garment sector (Bangladesh) and is running pilots in a variety of industry sectors in Mozambique.

Nutrition is a gendered issue, with constructs of masculinity and femininity frequently playing important roles in how both men and women procure and consume food - as well as the roles they play along the food value chain. In many LMIC settings, women are at an acute disadvantage because of these gender norms, facing constraints to income generation, travel, and other food access-related variables, as well as cultural sanctions on certain foods.

To better understand the implications of gender norms for workforce nutrition programming in LMICs, GAIN conducted a rapid review of recent literature on gender equity and nutrition in the workplace. The objective of this review is to inform a strategy to increase the gender sensitivity of GAIN's Workforce Nutrition programme. Adapting an existing conceptual framework depicting pathways to nutrition outcomes for agricultural households (2), this review explores how formal employment interacts with underlying gendered power relationships (at home and in the workplace), with implications for gender equity and nutrition.

\section{METHODS}

This review followed a simplified 'rapid review' format to provide an evidence synthesis for discussion and programme guidance (3). The review is limited to existing evidence and theory that provides insights into promoting equitable nutrition in the workplace in LMICs. The review focused on four intervention areas-healthy food at work, nutrition education, nutrition-focused health checks, and breastfeeding support-for vulnerable adult workers in LMICs.

The literature search was undertaken in September-December 2020 using a variety of keyword combinations ${ }^{1}$. Two online databases - PubMed and Google Scholar - as well as

\footnotetext{
1 Search terms include: Women or gender or "women's rights" or "gender sensitive" or "gender transformative" or "genderbased violence" AND Workers or "vulnerable workers" or "factory workers" or employees or workforce or "supply-chain
} 
databases of relevant international organisations ${ }^{2}$ were used. For each combination of keywords, the first 100 result were reviewed for relevance. Criteria for inclusion included: a focus on gender, plus one of the relevant programme areas listed above; publication year between 2000 and 2020; and English-language publication. Publications with a focus on LMICs were prioritised. Additional relevant studies were added during the review process based on references in selected papers and targeted searches to fill in gaps in the review. As such, papers published between 2000-2021 were ultimately included.

In total, 124 papers were identified to be potentially relevant for this review, of which 29 were selected for inclusion (complete list of papers can be found in the Annex). Of the included publications, $21 \%$ focus on LMICs in general or across regions, $58 \%$ focus on countries in Asia, and $21 \%$ on countries in Africa. All included literature was published in the past twenty years, and $79 \%$ of the included literature was published in the past ten years. Most sources used in this review are peer-reviewed journal articles (75\%); $14 \%$ are reports published by United Nations organisations, $7 \%$ are reports from other organisations; and $4 \%$ are books.

\section{VISUALISING WORKFORCE NUTRITION THROUGH A GENDER LENS}

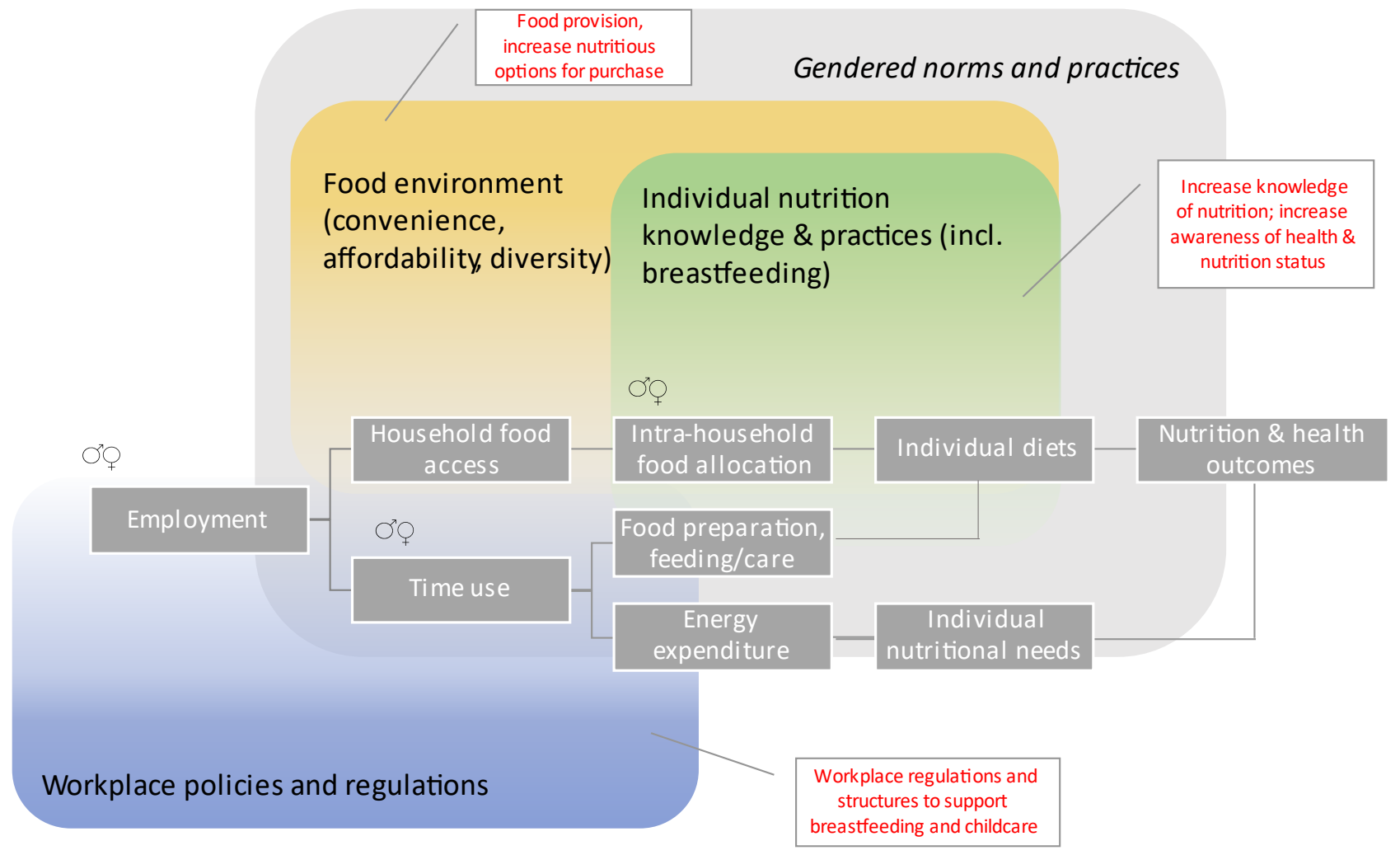

\footnotetext{
workers" or "agricultural workers" or "food system workers" or workplace AND Health or nutrition or "food security" or "breastfeeding support" or "nutrition focused health checks" or "nutrition education" or "nutrition Information Education Communications (IEC) or "behaviour change communication" or "healthy food at work" or "gender specific nutritional needs" or "pregnant and lactating" or "occupational health and safety" or "employee health" or harassment. Searches were undertaken with and without regional specifiers: LMIC or Africa or Asia

2 International Labour Organization, World Food Programme, Food and Agriculture Organization of the United Nations, UN Women, International Food Policy Research Institute, and Women's Empowerment in Agribusiness Index.
} 
Figure 1. Gendered pathways from employment to nutrition outcomes. Gender symbols denote where gendered agency particularly influences outcomes. Red text indicates potential programme entry points to facilitate gender equity and improved nutrition.

(Source: Authors, modified from (4))

A conceptual framework was developed to highlight the main gendered pathways through which employment influences nutrition outcomes (Figure 1, grey boxes depict pathways). The framework shows how nutrition for workers is modified by workplace policies and regulations (blue box), as well as the existing food environment (yellow box) and an individual's nutrition knowledge and practices (green box).

Workers in LMIC countries are more likely to engage in manual labour and more likely to consume inadequate food and nutrients to support this labour (5). Furthermore, workers without formal contracts and in contexts without strong workplace regulations may be even more vulnerable $(6,7)$. While these are challenges faced by all workers, gender norms often exacerbate these challenges for women.

Women are likely to experience limitations to finding and keeping work, dual burden of domestic duties and work duties, and exploitation and violence due to limited agency (8). Women also tend to be employed in low-wage and temporary positions with fewer rights (7). And their lack of agency and economic vulnerability may make them less likely to speak up for their rights at the workplace, even if equitable and nutrition-sensitive workplace regulations and policies are in place (9).

Two of the most common out-of-the-home, non-farm employment options for women in LMICs - garment work in textile factories and work on agricultural estates - are often unregulated, leaving workers exposed to marginalisation, exploitation, and violence, with little recourse to advocate for healthier work environments (6,7,9-11). Naved et al. (7), Newman et al. (12), and Philips (13) describe these sectors (along with healthcare) as 'feminised' and facing pervasive challenges related to discriminatory gender norms.

At the most proximate, biological level, the type and amount of work undertaken by an individual will determine energy requirements, and women and men have different nutritional needs at different stages of the lifecycle (14). Working women do not necessarily need fewer calories than men, as they may work longer hours and have caretaking and household responsibilities in addition to their paid work, women of childbearing age are more vulnerable to anaemia and osteoporosis than men, and pregnant and lactating women require extra calories and folic acid for optimal physical and congenital development of their babies (5).

\section{RESULTS}

The review that follows is organised to explore how common approaches to supporting workforce nutrition-enhancing workers' access to healthy food, health and nutrition promotion at work ${ }^{3}$, and support for breastfeeding-interact with pathways from

\footnotetext{
3 This section combines the discussion for two programme areas, nutrition education and nutrition-focused health checks, which both promote awareness of behaviours that support nutrition.
} 
employment to nutrition and how gender norms and practices can facilitate or compromise results.

\section{ENHANCING WORKERS' ACCESS TO HEALTHY FOOD}

Workers in many large-scale workplaces, like garment factories and agricultural estates, live on-site in corporate housing or in nearby communities primarily made up of factory or estate workers. Limitations to adequate food and nutrition in this context may occur for men and women if the workplace does not provide adequate time for breaks, or nutritious meals and snacks are not available and convenient. Furthermore, unhealthy food environments in the workplace can pose a challenge that extends beyond the worker and workday to the household level when workers live on-site in corporate housing or in nearby communities. As such, workers and their families are affected by what foods are convenient and affordable, as well as the quality of cooking and sanitation facilities in their homes. Because women are traditionally responsible for meal preparation and feeding of children, the burden of mitigating unhealthy food environments falls primarily on their shoulders.

Improving the quality of food available_prepared food and fresh food-around the workplace can support healthy diets. In Guatemala, Oddo et al. (6) find that working mothers are exposed to prepared take-away foods more often than non-employed mothers and spend less time on meal preparation and food procurement. Similarly, in Myanmar's garment sector, limited time to buy fresh foods and corporate housing without cooking facilities led women to rely on ready-to-eat or street food (14).

Provision of healthy meals at work can improve food security and-if attention is paid to food quality and diversity-nutritional status of workers. Hossain et al. (15) found that workplace lunch meals with weekly iron-folic acid supplements and monthly nutrition behaviour change reduced anaemia among female workers in Bangladesh by $46 \%$.

Even if healthy food is available and convenient, female workers may lack control over income, limiting their ability to purchase healthy foods for themselves or their families. For instance, women are often obligated to turn wages over to husbands or other family members (7) or send them as remittances to their families (14). Provision of free or subsidised food at work can help support healthy diets despite this.

\section{HEALTH AND NUTRITION PROMOTION AT WORK}

Workforce-based nutrition education programmes and nutrition-focused health checks promote awareness of nutritional status and support healthy behaviours and food choices of workers. Multiple evidence reviews of these types of health and nutrition programmes suggest that these programmes can improve diets, for instance, by increasing consumption of fruits and vegetables (16-18). In addition to frequently engaging workers themselves in the design of the programme, successful initiatives often include multiple components, such as combining nutrition education, health checks, healthy food provision, or physical activity promotion (in high-income settings). Hossain et al. (15), for example, found that workplace 
lunch meals that were combined with weekly iron-folic acid supplements and monthly nutrition behaviour change communication reduced anaemia in female workers by $46 \%$.

Women traditionally procure and prepare family meals, and nutrition education programmes thus often target women. However, this orientation may reinforce traditional gender norms, and it also overlooks the important role that men and other family members play in food consumption through control over income or enforcement of social norms (13). For example, evidence from a community-based setting in Malawi suggests that including men and women in nutrition education makes messages more likely to be adopted by the household (4).

Furthermore, engaging only women in nutrition education programmes can backfire, as it can add to women's already significant time burdens due to professional and household/childcare responsibilities and women may have limited agency to implement changes to household food consumption patterns $(4,11)$.

It is important to note that gendered barriers related to workforce nutrition programmes do not only affect women. Men may be reluctant to participate in health checks and health and nutrition education programmes; the literature describes the 'men's health gap', wherein men are less likely than women to participate in health-promoting activities $(19,20)$. In fact, men are often reluctant to actively engage with their own health in general, due to constructs of masculinity that encourage being stoic, disregarding physical risks, and 'powering through' injuries, illness, and other health issues (19-21). These norms are at odds with the fact that men face important health and nutrition problems that should not be overlooked. Examples from the review include a study that found that single male-headed households (divorced, widowed, or unmarried men) have lower average household dietary diversity scores than single female-headed households (4), and two studies that documented the challenge of anaemia in men $(22,23)$. While this micronutrient deficiency is a commonly recognised problem among women, it also affects men, with implications for productivity and well-being. With respect to countering the harmful health effects of masculine constructs, health education has been shown to support men's participation in health checks (20). Additionally, a systematic review of barriers and facilitators to health screening in men found that encouragement from their partner was the most important factor, reinforcing the benefit of engaging both partners in nutrition promotion (24).

Rebalancing the focus of health and nutrition policies and programmes for women and men not only encourages men to more actively support their health but also begins to challenge gendered stereotypes, avoids putting additional time pressure on women only, and supports the likelihood that nutrition practices will be adopted at home $(4,19)$.

\section{WORKPLACE-BASED SUPPORT TO BREASTFEEDING}

Promotion of breastfeeding is critical to improving nutrition knowledge and practices in many countries. Within the workplace, the main concern is the precipitous decline in breastfeeding that occurs when mothers go back to work, negatively affecting the health of mother and child $(25,26)$. Evidence shows that this decline can be countered by educating mothers and employers and by mandating supportive physical infrastructure and policies that permit breastfeeding and milk expression within the workplace (27). 
Given the sensitive and gendered nature of breastfeeding, as well as women's subordinance and vulnerability in many LMIC workplace settings, the extent to which workplace policies and regulations genuinely address constraints to breastfeeding is critically important $(28,29)$. To date, there are often substantial gaps between what a company's stated policy is and what happens in reality. For instance, in Indonesia, although workplaces are mandated by law to provide lactation facilities, Wagiu Basrowi et al. (25) found that companies are not held accountable when they fail to comply. In Ethiopia, Gebrekidan et al. (30) reported that while women were ostensibly allowed to take breaks to breastfeed their infants, they relied on coworkers to cover their workload and could only ask for such favours a few times before colleagues would be upset.

In these and similar cases, supporting mothers to breastfeed or pump breastmilk requires that workplaces have routine break times that are supported and enforced by management (31), as well as a private, clean space where women feel comfortable and safe. In addition to providing material and regulatory support, employers can encourage recommended breastfeeding practices through community outreach campaigns that aim to sensitise husbands and extended family members to the challenge faced by new mothers who must balance heavy burdens of professional and domestic work in order to continue breastfeeding $(30,32)$.

\section{DISCUSSION}

Entering the workforce can enable women's economic empowerment and thus lead to increased agency in their work and home lives. However, findings from this review indicate that many women continue to experience vulnerability and exploitation in the workplace in LMICs. This reality is likely to counter efforts to improve their nutritional status, as many of the pathways to improved nutrition rely on women's agency and bargaining power (33). Furthermore, gender norms that limit women's agency also make men less likely to likely to engage in their own health and nutrition.

Formal policies and regulations that promote nutrition in the workplace and that are sensitive to gender norms can help improve the situation $(7,11,14,28)$. Keen attention should be paid to the vulnerabilities women face and the gender norms that constrain men's and women's roles in a healthy workplace and home. Context-specific explorations should consider unintended consequences of how workforce nutrition interventions are designed as well as potential for shifting detrimental norms whenever possible.

For example, holding nutrition programmes during paid working hours will both mitigate women's time poverty and encourage men to participate. It is clear from the evidence reviewed that actively engaging men and women in nutrition programming, like nutrition education and nutrition-focused health checks, is more effective than engaging women alone-or not considering gender in targeting — when it comes to encouraging better nutrition for workers and their households $(4,20)$

When possible, it is important to engage not only workers but also family members and the broader community in which workers reside $(16,18)$. This approach also has the potential to begin to shift detrimental norms that have men neglecting their own health and lays 
responsibility—without equivalent agency—for care and feeding of the family predominantly on women (19).

Furthermore, analyses of workers' food environments and constraints on food procurement and preparation should include consideration of women's time, economic constraints, and other responsibilities. For instance, healthy daytime meals must be coupled with enforced break time, and free meals (compared to subsidised or full-price meals) will particularly benefit women with little or no control over their incomes $(5,31)$. In addition, consideration of the local food environment should include the convenience and affordability of fresh healthy foods and access to sanitary cooking facilities.

\section{CONCLUSIONS}

There is a large set of programmes and activities that can be put in place to support nutrition in the workplace. In this review we considered nutrition education programmes, nutritionfocused health checks, breastfeeding support and promotion, and improving availability of and access to healthy and nutritious food at/near work. The evidence reviewed suggests that these approaches have substantial potential to improve nutrition for vulnerable workers and their families.

Concomitant to these generic programme recommendations, it is critical to consider the capacity of a specific population of workers to take advantage of such opportunities. This is because workforce activities interact with gendered norms and power dynamics with important implications for women's and men's ability and willingness to utilise nutrition services.

Implementers of workforce nutrition programmes face a difficult decision on when and to what extent they can or should attempt to circumvent or transform the norms and power structures at play. Some solutions have been offered above, such as supporting both women and men (at work and at home) to participate in nutrition education and nutrition-focused health checks. Combined with improving the food environment by ensuring access to nutritious foods and adequate cooking facilities, these activities have the potential to overcome some gendered constraints.

In workplaces where female workers largely report to male managers, gendered power imbalances produce additional barriers to behaviours that support nutrition and health for women. For instance, even if there is a breastfeeding policy in place, women may hesitate to make use of breastfeeding infrastructure (e.g., 'breastfeeding corners') if male management is not overtly supportive or their workload is not adjusted to account for this time away from work, especially if broader societal norms do not encourage continued breastfeeding.

Strong engagement with management before and during-including training for management-workforce nutrition programmes will support genuine buy-in and awareness raising (7). Furthermore, engagement with, or establishment of, workforce welfare committees or similar may be useful for accessing workers directly and for exerting pressure on management. Finally, engagement with government regulatory bodies (within ministries 
of labour, for instance) may improve the enabling environment in which the companies operate. 


\section{REFERENCES}

[1. Food and Agricultural Organization. The State of Food Security and Nutrition in the World 2021. The State of Food Security and Nutrition in the World. Rome, Italy: Food and Agricultural Organization; 2021.

2. Herforth A, Harris J. Understanding and Applying Primary Pathways and Principles. Arlington, VA: USAID/Strengthening Partnerships, Results, and Innovations in Nutrition Globally (SPRING) Project; 2014. (Improving Nutrition through Agriculture Technical Brief Series). Report No.: Brief \#1.

3. Khangura S, Konnyu K, Cushman R, Grimshaw J, Moher D. Evidence summaries: The evolution of a rapid review approach. Syst Rev. 2012;1(1):1-9.

4. Ragasa C, Aberman NL, Alvarez Mingote C. Does providing agricultural and nutrition information to both men and women improve household food security? Evidence from Malawi. Glob Food Sec [Internet]. 2019;20(December 2018):45-59. Available from: https://doi.org/10.1016/j.gfs.2018.12.007

5. Wanjek C. Food at Work: Workplace solutions for malnutrition, obesity and chronic diseases. Geneva; 2005.

6. Oddo VM, Ickes SB. Maternal employment in low-and middle-income countries is associated with improved infant and young child feeding. Am J Clin Nutr. 2018;107(3):335-44.

7. Naved RT, Mamun M Al, Parvin K, Willan S, Gibbs A, Jewkes R. Learnings from the evaluation of HERrespect: a factory-based intervention to prevent intimate partner and workplace violence against female garment workers in Bangladesh. Glob Health Action [Internet]. 2021;14(1). Available from: https://doi.org/10.1080/16549716.2020.1868960

8. Morton M, Klugman J, Hanmer L, Singer D. Gender at work: A companion to the World Development Report on Jobs [Internet]. Washington D.C.; 2014. Available from: http://documents.worldbank.org/curated/en/884131468332686103/Gender-at-work-acompanion-to-the-world-development-report-on-jobs

9. Siddiqi DM. The Sexual Harassment of Industrial Workers: Strategies for Intervention in the Workplace and Beyond Centre for Policy Dialogue. 2003.

10. Brown K, Henretty N, Chary A, Webb MF, Wehr H, Moore J, et al. Mixed-methods study identifies key strategies for improving infant and young child feeding practices in a highly stunted rural indigenous population in Guatemala. Matern Child Nutr. 2016;12(2):262-77.

11. Dishanka S, Ikemoto Y. Justice in the Tea Estate Community in Sri Lanka: An Explanation through Freedom-based Capability Approach. J Soc Dev Sci [Internet]. 2018 Apr 19 [cited 2021 Apr 29];9(1):6-18. Available from: https://ojs.amhinternational.com/index.php/jsds/article/view/2164

12. Newman CJ, de Vries DH, d'Arc Kanakuze J, Ngendahimana G. Workplace violence and gender discrimination in Rwanda's health workforce: Increasing safety and gender equality. Hum Resour Health [Internet]. 2011 Jul 19 [cited 2021 Apr 29];9(1):19. Available from: https://human-resourceshealth.biomedcentral.com/articles/10.1186/1478-4491-9-19

13. Philips A. Rethinking culture and development: marriage and gender among the tea plantation workers in Sri Lanka. Gend Dev [Internet]. 2003 [cited 2021 Apr 29];11(2):20-9. Available from: 
https://www.tandfonline.com/doi/abs/10.1080/741954313

14. Goudet S, Hlaing LM, Griffiths PL. Exploring food security and nutrition among young women in the formally regulated garment sector of Myanmar. Ann N Y Acad Sci. 2020;1468(1):35-54.

15. Hossain M, Islam Z, Sultana S, Rahman AS, Hotz C, Haque A, et al. Effectiveness of Workplace Nutrition Programs on Anemia Status among Female Readymade Garment Workers in Bangladesh: A Program Evaluation. Nutrients [Internet]. 2019 [cited 2021 Apr 29];11. Available from: www.mdpi.com/journal/nutrients

16. Ni Mhurchu C, Aston LM, Jebb SA. Effects of worksite health promotion interventions on employee diets: A systematic review. BMC Public Health. 2010;10.

17. Geaney F, Kelly C, Greiner BA, Harrington JM, Perry IJ, Beirne P. The effectiveness of workplace dietary modification interventions: A systematic review [Internet]. Vol. 57, Preventive Medicine. Prev Med; 2013 [cited 2021 Apr 29]. p. 438-47. Available from: https://pubmed.ncbi.nlm.nih.gov/23850518/

18. Anderson J, Parker W, Steyn; NP, Grimsrud A, Kolbe-Alexander T, Lambert EV, et al. Interventions on diet and physical activity: what works: summary report [Internet]. Geneva: World Health Organization; 2009 [cited 2021 May 11]. Available from: www.blossoming.it

19. Baker P, Dworkin SL, Tong S, Banks I, Shand T, Yamey G. The men's health gap: men must be included in the global health equity agenda. Bull World Heal Organ. 2014;

20. Teo $\mathrm{CH}, \mathrm{Ng} \mathrm{CJ}$, Booth $\mathrm{A}$, White A. Barriers and facilitators to health screening in men: A systematic review. Soc Sci Med. 2016 Sep 1;165:168-76.

21. Betron M, Barker G, Contreras JM, Peacock D. Men, masculinities and HIV/AIDS: Strategies for action. Int Cent Res Women, Inst Promundo, MenEngage Alliance, Sonke Gend Justice Netw. 2012;

22. Scott S, Pant A, Nguyen P, Alderman H, Yadav K, Menon P. Anemia in Indian Men Predicts Fewer Work Hours and Lower Earnings: Evidence from Nationally Representative Health and Labor Surveys. Curr Dev Nutr [Internet]. 2020 Jun 1 [cited 2021 Apr 29];4(Supplement_2):1838-1838. Available from:

https://academic.oup.com/cdn/article/4/Supplement_2/1838/5845653

23. Rahman Khan M, Ahmed F. Physical status, nutrient intake and dietary pattern of adolescent female factory workers in urban Bangladesh. Vol. 14, Asia Pac J Clin Nutr. 2005.

24. Teo $\mathrm{CH}, \mathrm{Ng} \mathrm{CJ}$. This is a repository copy of Barriers and facilitators to health screening in men: A systematic review. [cited 2021 Sep 15]; Available from: http://eprints.whiterose.ac.uk/104544/

25. Wagiu Basrowi R, Sastroasmoro S, Sulistomo AW, Bardosono S, Hendarto A, Soemarko DS, et al. PGHN Challenges and Supports of Breastfeeding at Workplace in Indonesia. Pediatr Gastroenterol Hepatol Nutr [Internet]. 2018 [cited 2021 May 10];(4):248-56. Available from: https://doi.org/10.5223/pghn.2018.21.4.248

26. Ickes SB, Oddo VM, Sanders HK, Nduati R, Denno DM, Myhre JA, et al. Formal maternal employment is associated with lower odds of exclusive breastfeeding by 14 weeks postpartum: a cross-sectional survey in Naivasha, Kenya. Am J Clin Nutr. 2021;113(3):562-73.

27. Dinour LM, Szaro JM. Employer-Based Programs to Support Breastfeeding among 
Working Mothers: A Systematic Review [Internet]. Vol. 12, Breastfeeding Medicine. Mary Ann Liebert Inc.; 2017 [cited 2021 Apr 29]. p. 131-41. Available from: https://pubmed.ncbi.nlm.nih.gov/28394659/

28. World Health Organization. Building healthy and equitable workplaces for women and men: a resource for employers and worker representatives [Internet]. Geneva; 2011 [cited 2021 Apr 29]. (Protecting Workers' Health Series). Report No.: No. 11. Available from: http://www.who.int/about/licensing/copyright_form/en/index.html

29. Horwood C, Surie A, Haskins L, Luthuli S, Hinton R, Chowdhury A, et al. Attitudes and perceptions about breastfeeding among female and male informal workers in India and South Africa. BMC Public Health [Internet]. 2020 Jun 5 [cited 2021 May 10];20(1):1-12. Available from: https://doi.org/10.1186/s12889-020-09013-9

30. Gebrekidan K, Plummer V, Fooladi E, Hall H. Attitudes and experiences of employed women when combining exclusive breastfeeding and work: A qualitative study among office workers in Northern Ethiopia. Matern Child Nutr. 2021 Apr 8;

31. Whelan M. Put women's nutrition on the workplace menu. Occupational health and wellbeing [Internet]. 2018 Jun 1 [cited 2021 May 11]; Available from: https://www.personneltoday.com/hr/put-womens-nutrition-on-the-workplace-menu/

32. Hirani SAA, Karmaliani R. Evidence based workplace interventions to promote breastfeeding practices among pakistani working mothers. Vol. 26, Women and Birth. Elsevier; 2013. p. 10-6.

33. van den Bold M, Quisumbing AR, Gillespie S. Women's Empowerment and Nutrition: An Evidence Review. Washington DC; 2013. (IFPRI Discussion Paper). Report No.: 1294. 
ANNEX

Table 1: List of reviewed literature, geographic coverage, and topic

\begin{tabular}{|c|c|c|c|}
\hline Author (year) & Country (setting) & Topics covered & Type \\
\hline Anderson et al. (2009) & $\begin{array}{l}\text { Multiple regions } \\
\text { (LMICs) }\end{array}$ & $\begin{array}{l}\text { Implications for } \\
\text { nutrition education }\end{array}$ & $\begin{array}{l}\text { UN organisation } \\
\text { report }\end{array}$ \\
\hline Baker et al. (2014) & $\begin{array}{l}\text { Multiple regions } \\
\text { (LMICs and high- } \\
\text { income countries, } \\
\text { HICs) }\end{array}$ & $\begin{array}{l}\text { Nutrition-focused } \\
\text { health checks: needs } \\
\text { of men and women }\end{array}$ & $\begin{array}{l}\text { Peer-reviewed } \\
\text { journal article }\end{array}$ \\
\hline $\begin{array}{l}\text { Betron, Barker, } \\
\text { Contreras \& Peacock } \\
\text { (2012) }\end{array}$ & $\begin{array}{l}\text { Multiple regions } \\
\text { (LMICs) }\end{array}$ & $\begin{array}{l}\text { Nutrition-focused } \\
\text { health checks: needs } \\
\text { of men and women }\end{array}$ & $\begin{array}{l}\text { UN organisation } \\
\text { report }\end{array}$ \\
\hline Brown et al. (2016) & $\begin{array}{l}\text { Haiti, Indonesia, } \\
\text { Jordan, Nicaragua, } \\
\text { and Vietnam }\end{array}$ & $\begin{array}{l}\text { Workplace } \\
\text { harassment }\end{array}$ & $\begin{array}{l}\text { Report from } \\
\text { organisation } \\
\text { (non-UN) }\end{array}$ \\
\hline Dinour \& Szaro (2017) & & $\begin{array}{l}\text { Breastfeeding } \\
\text { support for women: } \\
\text { cultural norms }\end{array}$ & $\begin{array}{l}\text { Peer-reviewed } \\
\text { journal article }\end{array}$ \\
\hline $\begin{array}{l}\text { Dishanka \& Ikemoto } \\
\text { (2018) }\end{array}$ & Sri Lanka & $\begin{array}{l}\text { Workplace } \\
\text { harassment }\end{array}$ & $\begin{array}{l}\text { Peer-reviewed } \\
\text { journal article }\end{array}$ \\
\hline Game \& Pringle (2020) & Australia & $\begin{array}{l}\text { Dual burdens or } \\
\text { care-implications for } \\
\text { working parents; } \\
\text { workplace } \\
\text { harassment }\end{array}$ & Book \\
\hline Geaney et al. (2013) & $\begin{array}{l}\text { Brazil, USA, } \\
\text { Netherlands, and } \\
\text { Belgium }\end{array}$ & $\begin{array}{l}\text { Implications for } \\
\text { nutrition education }\end{array}$ & $\begin{array}{l}\text { Peer-reviewed } \\
\text { journal article }\end{array}$ \\
\hline $\begin{array}{l}\text { Gebrekidan, Plummer, } \\
\text { Fooladi \& Hall (2021) }\end{array}$ & Ethiopia & $\begin{array}{l}\text { Breastfeeding } \\
\text { support for women: } \\
\text { time allocation }\end{array}$ & $\begin{array}{l}\text { Peer-reviewed } \\
\text { journal article }\end{array}$ \\
\hline $\begin{array}{l}\text { Goudet, Hlaing \& } \\
\text { Griffiths (2020) }\end{array}$ & Myanmar & $\begin{array}{l}\text { Access to healthy } \\
\text { food at work: } \\
\text { different nutritional } \\
\text { needs of men and } \\
\text { women (different } \\
\text { nutritional health risk } \\
\text { factors) }\end{array}$ & $\begin{array}{l}\text { Peer-reviewed } \\
\text { journal article }\end{array}$ \\
\hline $\begin{array}{l}\text { Gurung \& Mukherjee } \\
\text { (2018) }\end{array}$ & India & $\begin{array}{l}\text { Social norms } \\
\text { affecting gender } \\
\text { relations at the } \\
\text { workplace }\end{array}$ & $\begin{array}{l}\text { Peer-reviewed } \\
\text { journal article }\end{array}$ \\
\hline
\end{tabular}




\begin{tabular}{|c|c|c|c|}
\hline $\begin{array}{l}\text { Hirani, Ali \& Karmaliani } \\
\text { (2013) }\end{array}$ & Pakistan & $\begin{array}{l}\text { Breastfeeding } \\
\text { support for women: } \\
\text { cultural norms }\end{array}$ & $\begin{array}{l}\text { Peer-reviewed } \\
\text { journal article }\end{array}$ \\
\hline Hossain et al. (2019) & Bangladesh & $\begin{array}{l}\text { Access to healthy } \\
\text { food at work: } \\
\text { creating access to } \\
\text { healthy food at work } \\
\text { with direct food } \\
\text { provision of meals at } \\
\text { the workplace }\end{array}$ & $\begin{array}{l}\text { Peer-reviewed } \\
\text { journal article }\end{array}$ \\
\hline Ickes et al. (2021) & Kenya & $\begin{array}{l}\text { Breastfeeding } \\
\text { support for women }\end{array}$ & $\begin{array}{l}\text { Peer-reviewed } \\
\text { journal article }\end{array}$ \\
\hline Naved et al. (2021) & Bangladesh & $\begin{array}{l}\text { Workplace } \\
\text { harassment }\end{array}$ & $\begin{array}{l}\text { Peer-reviewed } \\
\text { journal article }\end{array}$ \\
\hline $\begin{array}{l}\text { Newman, De Vries, } \\
\text { Kanakuze \& } \\
\text { Ngendahimana (2011) }\end{array}$ & Rwanda & $\begin{array}{l}\text { Workplace } \\
\text { harassment }\end{array}$ & $\begin{array}{l}\text { Peer-reviewed } \\
\text { journal article }\end{array}$ \\
\hline $\begin{array}{l}\text { Ni Mhurchu, Aston \& } \\
\text { Jebb (2010) }\end{array}$ & $\begin{array}{l}\text { North America, } \\
\text { Europe }\end{array}$ & $\begin{array}{l}\text { Implications for } \\
\text { nutrition education }\end{array}$ & $\begin{array}{l}\text { Peer-reviewed } \\
\text { journal article }\end{array}$ \\
\hline Oddo \& Ickes (2018) & $\begin{array}{l}\text { Multiple regions } \\
\text { (LMICs) }\end{array}$ & $\begin{array}{l}\text { Access to healthy } \\
\text { food at work: } \\
\text { creating access to } \\
\text { healthy food at work }\end{array}$ & $\begin{array}{l}\text { Peer-reviewed } \\
\text { journal article }\end{array}$ \\
\hline Philips (2003) & Sri Lanka & $\begin{array}{l}\text { Implications for } \\
\text { nutrition education: } \\
\text { implications for } \\
\text { messaging }\end{array}$ & $\begin{array}{l}\text { Peer-reviewed } \\
\text { journal article }\end{array}$ \\
\hline $\begin{array}{l}\text { Ragasa, Aberman \& } \\
\text { Mingote (2019) }\end{array}$ & Malawi & $\begin{array}{l}\text { Implications for } \\
\text { nutrition education: } \\
\text { implications for } \\
\text { messaging }\end{array}$ & $\begin{array}{l}\text { Peer-reviewed } \\
\text { journal article }\end{array}$ \\
\hline $\begin{array}{l}\text { Rahman Khan \& Ahmed } \\
\text { (2005) }\end{array}$ & Bangladesh & $\begin{array}{l}\text { Nutrition-focused } \\
\text { health checks: needs } \\
\text { of men and women }\end{array}$ & $\begin{array}{l}\text { Peer-reviewed } \\
\text { journal article }\end{array}$ \\
\hline Scott et al. (2020) & India & $\begin{array}{l}\text { Nutrition-focused } \\
\text { health checks: needs } \\
\text { of men and women }\end{array}$ & $\begin{array}{l}\text { Peer-reviewed } \\
\text { journal article }\end{array}$ \\
\hline Siddiqi (2003) & Bangladesh & $\begin{array}{l}\text { Workplace } \\
\text { harassment }\end{array}$ & $\begin{array}{l}\text { Report from } \\
\text { organisation } \\
\text { (non-UN) }\end{array}$ \\
\hline $\begin{array}{l}\text { Street, Lacey \& } \\
\text { Grambower (2017) }\end{array}$ & Australia & $\begin{array}{l}\text { Nutrition-focused } \\
\text { health checks: needs } \\
\text { of men and women }\end{array}$ & $\begin{array}{l}\text { Peer-reviewed } \\
\text { journal article }\end{array}$ \\
\hline
\end{tabular}




\begin{tabular}{|l|l|l|l|}
\hline Teo et al. (2016) & $\begin{array}{l}\text { Multiple regions } \\
\text { (LMICs and HICs) }\end{array}$ & $\begin{array}{l}\text { Nutrition-focused } \\
\text { health checks: needs } \\
\text { of men }\end{array}$ & $\begin{array}{l}\text { Peer-reviewed } \\
\text { journal article }\end{array}$ \\
\hline (2018) & Indonesia & $\begin{array}{l}\text { Breastfeeding } \\
\text { support for women: } \\
\text { laws around parental } \\
\text { leave }\end{array}$ & $\begin{array}{l}\text { Peer-reviewed } \\
\text { journal article }\end{array}$ \\
\hline Wanjek (2005) & $\begin{array}{l}\text { Multiple regions } \\
\text { (LMICs and HICs) }\end{array}$ & $\begin{array}{l}\text { Access to healthy } \\
\text { food at work: } \\
\text { different nutritional } \\
\text { needs of men and } \\
\text { women }\end{array}$ & $\begin{array}{l}\text { UN organisation } \\
\text { report }\end{array}$ \\
\hline Whelan (2018) & United Kingdom & $\begin{array}{l}\text { Nutrition-focused } \\
\text { health checks: needs } \\
\text { of men and women }\end{array}$ & $\begin{array}{l}\text { Peer-reviewed } \\
\text { journal article }\end{array}$ \\
\hline WHO (2011) & $\begin{array}{l}\text { Multiple regions } \\
\text { (LMICs and HICs) }\end{array}$ & $\begin{array}{l}\text { Social norms } \\
\text { affecting gender } \\
\text { relations at the } \\
\text { workplace }\end{array}$ & $\begin{array}{l}\text { UN organisation } \\
\text { report }\end{array}$ \\
\hline
\end{tabular}

